\title{
Labrys neptuniae sp. nov., isolated from root nodules of the aquatic legume Neptunia oleracea
}

\author{
Correspondence \\ Wen-Ming Chen \\ p62365@ms28.hinet.net
}

\author{
Yi-Ju Chou, ${ }^{1}$ Geoffrey N. Elliott, ${ }^{2}$ Euan K. James, ${ }^{2}$ Kuan-Yin Lin, ${ }^{1}$ \\ Jui-Hsing Chou, ${ }^{3}$ Shih-Yi Sheu, ${ }^{4}$ Der-Shyan Sheu, ${ }^{4}$ Janet I. Sprent ${ }^{2}$ \\ and Wen-Ming Chen ${ }^{1}$ \\ ${ }^{1}$ Laboratory of Microbiology, Department of Seafood Science, National Kaohsiung Marine \\ University, Kaohsiung City 811, Taiwan \\ ${ }^{2}$ School of Life Sciences, University of Dundee, Dundee DD1 5EH, UK \\ ${ }^{3}$ Department of Soil Environmental Science, College of Agriculture and Natural Resources, \\ National Chung Hsing University, Taichung, Taiwan \\ ${ }^{4}$ Department of Marine Biotechnology, National Kaohsiung Marine University, Kaohsiung, \\ Taiwan
}

\begin{abstract}
A bacterium designated strain Liujia-146 ${ }^{\top}$ was isolated in the Tainan area of southern Taiwan from root nodules of the aquatic legume Neptunia oleracea. $16 \mathrm{~S}$ rRNA gene sequence analysis indicated that strain Liujia-146 ${ }^{\top}$ was highly similar to Labrys monachus VKM B-1479 ${ }^{\top}(97.8 \%)$ and Labrys methylaminiphilus $\mathrm{JLW} 10^{\top}(95.5 \%)$ and belonged to the order Rhizobiales in the Alphaproteobacteria. On the basis of phylogenetic analysis, DNA-DNA hybridization data, physiological and biochemical characteristics and fatty acid compositions, the organism was shown to belong to the genus Labrys whilst representing a novel species within this genus. We propose to classify strain Liujia-146 ${ }^{\top}$ (=BCRC $17578^{\top}=$ LMG $\left.23578^{\top}\right)$ as the type strain of Labrys neptuniae sp. nov.
\end{abstract}

The pan-tropical mimosoid legume genus Neptunia has attracted much interest in the last 15 years, largely because of the aquatic habitat of some of its species and the ability of some of these to form $\mathrm{N}_{2}$-fixing root nodules on submerged roots (James et al., 1992a, b, 2001; Subba-Rao et al., 1995). A variety of bacteria have been isolated from such nodules, particularly from Neptunia oleracea (syn. N. natans, $N$. prostrata; http://www.ildis.org), including a species closely related to Rhizobium, Allorhizobium undicola (de Lajudie et al., 1998), and the alphaproteobacterium Devosia neptuniae (Rivas et al., 2002, 2003). In addition to these 'exotic' bacterial species, more 'conventional' rhizobia have also been isolated from Neptunia nodules, for example Rhizobium tropici strains UPRM8033 and DUS239 from Neptunia plena (Zurdo-Piñeiro et al., 2004). In the present study, we report on a novel non-nodulating strain from the genus Labrys, Liujia-146 ${ }^{\mathrm{T}}$, isolated from root nodules of $N$. oleracea growing aquatically in Taiwan. Labrys is a genus of budding bacteria, first described by Vasilyeva \& Semenov (1984). At present, it consists of two species, Labrys

The GenBank/EMBL/DDBJ accession number for the $16 \mathrm{~S}$ rRNA gene sequence of strain Liujia-146 ${ }^{\top}$ is DQ417335.

Fatty acid compositions and whole-cell protein profiles of strain Liujia$146^{\top}$ and related strains are available as supplementary material in IJSEM Online. monachus (Vasilyeva \& Semenov, 1984) and Labrys methylaminiphilus (Miller et al., 2005). Cells of L. monachus possess triangular radial symmetry (Vasilyeva \& Semenov, 1984) and L. methylaminiphilus is a facultative methylotroph (Miller et al., 2005). Comparisons of their 16S rRNA gene sequences indicate that L. monachus and L. methylaminiphilus belong to the Alphaproteobacteria (Fritz et al., 2004; Miller et al., 2005).

Root nodules were collected from $N$. oleracea growing in a freshwater pond at Tainan County in southern Taiwan. They were immersed in $75 \%$ ethanol for $10 \mathrm{~s}$, sterilized in $0.1 \%(\mathrm{w} / \mathrm{v})$ mercuric chloride for $10 \mathrm{~min}$ and then washed six times with sterile distilled water. Individual nodules were crushed and streaked onto yeast extract-mannitol (YEM) agar (Vincent, 1970) and incubated at $28^{\circ} \mathrm{C}$. The majority of isolates ( $>95 \%$ ) were identified as A. undicola. However, a bacterial strain with a colony morphology different from that of $A$. undicola was also recovered. This was designated Liujia-146 ${ }^{\mathrm{T}}$. Type strains of L. monachus (DSM 5896 ${ }^{\mathrm{T}}$ ) and L. methylaminiphilus (DSM $16812^{\mathrm{T}}$ ) were obtained from the DSMZ.

The $\mathrm{pH}$ range for growth was determined by measuring the optical density (wavelength $595 \mathrm{~nm}$ ) of cultures grown in YEM medium with $\mathrm{pH}$ ranging from 4 to 10 , adjusted with appropriate biological buffers (Chung et al., 1995). 


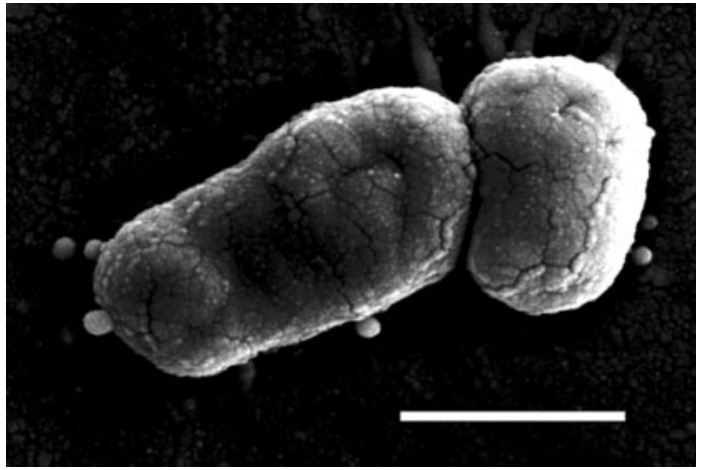

Fig. 1. Scanning electron micrograph of a cell of strain Liujia$146^{\top}$. Bar, $1 \mu \mathrm{m}$.

Anaerobic cultivation was performed on YEM medium under the Oxoid AnaeroGen system. Strain Liujia-146 ${ }^{\mathrm{T}}$ formed visible colonies that were circular, convex, opaque and mucoid with entire edges. The colony diameter was approximately $1.0-2.0 \mathrm{~mm}$ on YEM agar after $48 \mathrm{~h}$ of incubation at $28^{\circ} \mathrm{C}$. Strain Liujia- $146^{\mathrm{T}}$ grew well at temperatures ranging from 25 to $35^{\circ} \mathrm{C}$ and at a $\mathrm{pH}$ between 4 and 10; optimal growth conditions were $28-30{ }^{\circ} \mathrm{C}$ and $\mathrm{pH}$ 7.0-8.0. Strain Liujia- $146^{\mathrm{T}}$ did not require additional growth factors, although addition of yeast extract was found to stimulate growth. It did not grow over $120 \mathrm{~h}$ of incubation at $28{ }^{\circ} \mathrm{C}$ under anaerobic conditions, suggesting that it is an aerobic bacterium.

Cell morphology was observed under a light microscope and by scanning electron microscopy. Motility of cells was examined by the hanging drop method. Gram Stain Set S (Difco) and Indian ink (Difco) were used to perform Gram and capsule staining. Strain Liujia- $146^{\mathrm{T}}$ is a Gram-negative, non-motile, non-spore-forming, capsulated, rod-shaped bacterium, $0.7-0.9 \mu \mathrm{m}$ in diameter and $1.2-1.5 \mu \mathrm{m}$ in length (Fig. 1). Cells are found singly or in pairs and were seen to reproduce by budding. Capsule formation, observed by electron microscopy, was also visualized with Indian ink by light microscopy.

Amplification and sequence analysis of the 16S rRNA gene were performed as described elsewhere (Chen et al., 2001). Multiple-sequence alignment comparing strain Liujia-146 ${ }^{\mathrm{T}}$ and its closest relatives was performed using BioEdit software (Hall, 1999). Distances (distance options according to the Kimura two-parameter model) and clustering with the neighbour-joining and maximum-parsimony methods were determined by using bootstrap values based on 1000 replications. Comparison of the 16S rRNA gene sequence of strain Liujia- $146^{\mathrm{T}}$ with available $16 \mathrm{~S}$ rRNA gene sequences in public databases revealed that strain Liujia- $146^{\mathrm{T}}$ belonged to the order Rhizobiales of the Alphaproteobacteria. The highest similarity values were obtained from the comparison with $L$. monachus VKM B- $1479^{\mathrm{T}}$ (97.8\% similarity) and $L$. methylaminiphilus $\mathrm{JLW}^{\mathrm{T}}{ }^{\mathrm{T}}(95.5 \%)$. The two type strains of
Labrys species, VKM B-1479 ${ }^{\mathrm{T}}$ and $\mathrm{JLW} 10^{\mathrm{T}}$, and strain Liujia- $146^{\mathrm{T}}$ were found to form a well-separated, monophyletic group (Fig. 2). The $16 \mathrm{~S}$ rRNA gene sequence similarity of strain Liujia- $146^{\mathrm{T}}$ to other established bacterial species within the Alphaproteobacteria was less than $95 \%$. Recently, Lee et al. (2005) proposed a novel family Xanthobacteraceae of the order Rhizobiales to include the genera Labrys, Azorhizobium, Ancylobacter, Starkeya and Xanthobacter. However, our phylogenetic analysis based on neighbour-joining and maximum-parsimony methods did not support the affiliation of Labrys species within the family Xanthobacteraceae, which was based on only one species, $L$. methylaminiphilus.

DNA-DNA hybridization experiments were performed with strain Liujia- $146^{\mathrm{T}}$ and the two type strains of Labrys species using the method described by Ezaki et al. (1989), with data from experiments performed in triplicate indicating that the DNA-DNA binding level of strain Liujia- $146^{\mathrm{T}}$ with $L$. monachus VKM B-1479 ${ }^{\mathrm{T}}$ and $L$. methylaminiphilus $\mathrm{JLW} 10^{\mathrm{T}}$ was only $18.6( \pm 5.1) \%$ and $41.0( \pm 7.6) \%$, respectively. The DNA G $+\mathrm{C}$ content of strain Liujia- $146^{\mathrm{T}}$ was determined in triplicate using the method described by Mesbah et al. (1989) and was found to be $62.7( \pm 1.7) \mathrm{mol} \%$.

For biochemical characterization, the API 20NE, API ZYM (bioMérieux) and Microlog GN2 (Biolog) systems were used according to the manufacturers' instructions. Additionally, sensitivity to antibiotics was examined by spreading cells ( $0.5 \mathrm{McF}$ arland) onto YEM agar and placing onto them discs (Difco) containing the following individual antibiotics: ampicillin $(10 \mu \mathrm{g})$, chloramphenicol $(30 \mu \mathrm{g})$, gentamicin $(10 \mu \mathrm{g})$, kanamycin $(30 \mu \mathrm{g})$, nalidixic acid $(30 \mu \mathrm{g})$, novobiocin $(30 \mu \mathrm{g})$, rifampicin $(5 \mu \mathrm{g})$, penicillin $\mathrm{G}(10 \mathrm{U})$, streptomycin $(10 \mu \mathrm{g})$ and tetracycline $(30 \mu \mathrm{g})$. Results of biochemical characterization and antibiotic sensitivity are given in the species description.

Chemotaxonomic differentiation of strain Liujia- $146^{\mathrm{T}}$ from its closest phylogenetic neighbours was examined using several approaches. For analysis of protein electrophoretic patterns, preparation of whole-cell proteins and SDS-PAGE were performed as described by Pot et al. (1994). The wholecell protein profile of strain Liujia- $146^{\mathrm{T}}$ could be differentiated clearly from those of L. monachus VKM B-1479 ${ }^{\mathrm{T}}$ and L. methylaminiphilus $\mathrm{JLW}^{\mathrm{T}}{ }^{\mathrm{T}}$ (see Supplementary Fig. S1 available in IJSEM Online). For fatty acid methyl ester analysis, cell culture was harvested after an incubation period of $48 \mathrm{~h}$ at $28^{\circ} \mathrm{C}$; fatty acid methyl esters were then prepared, separated and identified according to the instructions of the Microbial Identification System (MIDI; Microbial ID). The major cellular fatty acids of strain Liujia$146^{\mathrm{T}}$ were $16: 0,18: 1 \omega 7 c$ and $19: 0$ cyclo, as found with $L$. monachus VKM B-1479 ${ }^{\mathrm{T}}$ and L. methylaminiphilus JLW $10^{\mathrm{T}}$ (Miller et al., 2005). However, strain Liujia-146 ${ }^{\mathrm{T}}$ could again be clearly distinguished from L. monachus VKM B-1479 ${ }^{\mathrm{T}}$ and $L$. methylaminiphilus $\mathrm{JLW} 10^{\mathrm{T}}$ by its significantly larger relative amount of $18: 1 \omega 7 c(68.8 \%)$, coupled with the 


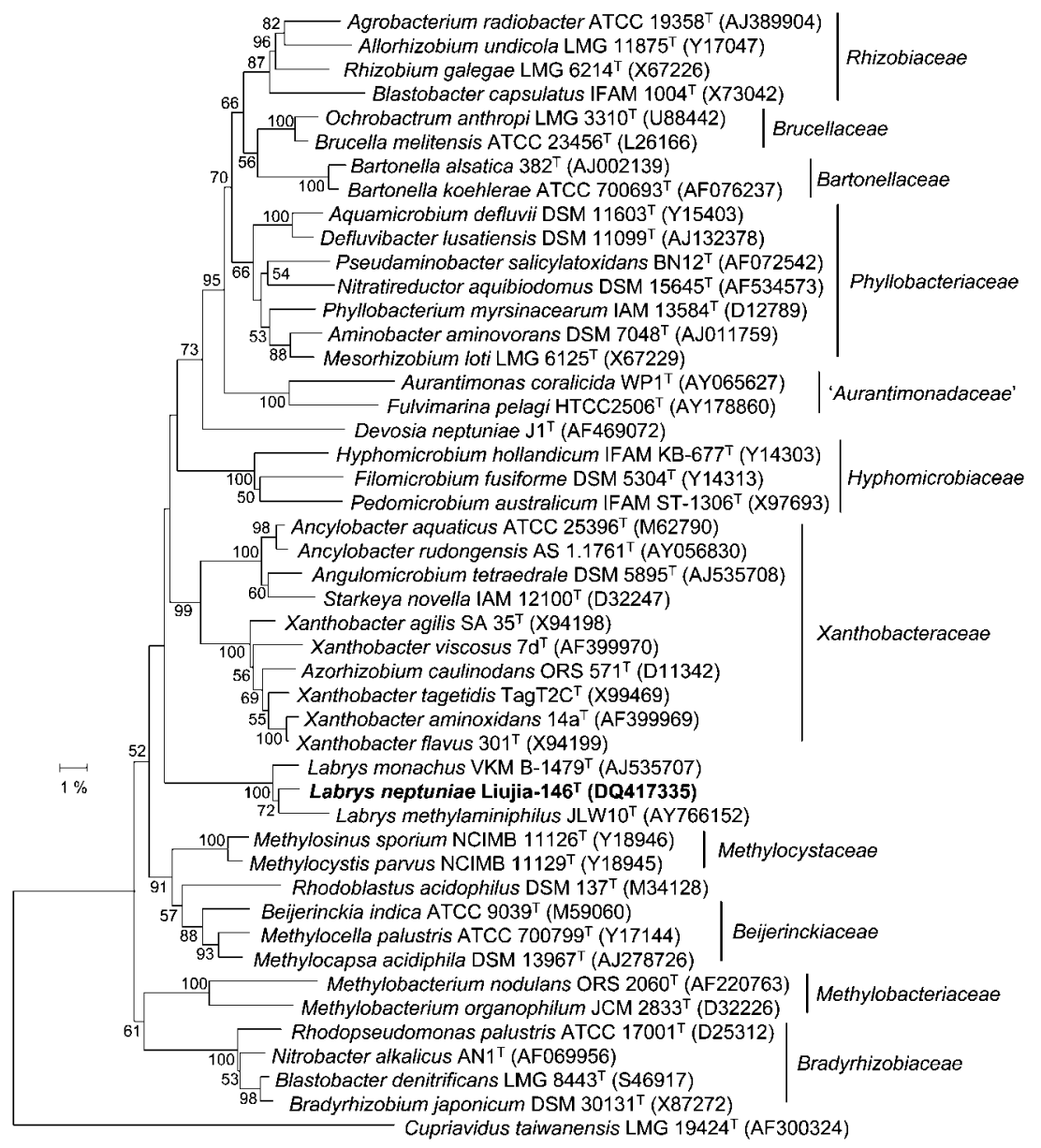

Fig. 2. Neighbour-joining phylogenetic tree of strain Liujia-146 ${ }^{\top}$ and related bacteria based on 16S rRNA gene sequence comparisons. Numbers at nodes are percentage bootstrap values based on 1000 resampled datasets; only values above $50 \%$ are given. Accession numbers are given in parentheses. Bar, $1 \%$ sequence dissimilarity. smaller relative amount of 19:0 cyclo (7.8\%) and the absence of detectable amounts of 20:169 (Table 1 and Supplementary Table S1 in IJSEM Online).

Plant cultivation and nodulation tests were carried out as described previously (Chen et al., 2003). Plants of $N$. oleracea and Macroptilium atropurpureum were harvested at 45 days after inoculation with strain Liujia- $146^{\mathrm{T}}$, and no nodules had formed by that time. This indicates that bacteria isolated from nodules are not necessarily able to induce nodulation.

Detailed comparison of the physiological and biochemical characteristics of strain Liujia-146 ${ }^{\mathrm{T}}$, L. monachus VKM B$1479^{\mathrm{T}}$ and L. methylaminiphilus $\mathrm{JLW}^{\mathrm{T}} 0^{\mathrm{T}}$ is shown in Table 1. Strain Liujia- $146^{\mathrm{T}}$ could be distinguished clearly from L. monachus VKM B-1479 ${ }^{\mathrm{T}}$ by many characters, especially regarding the capability for nitrite reduction, vitamin requirement for growth and assimilation of a variety of carbon substrates. Strain Liujia- $146^{\mathrm{T}}$ could also be distinguished clearly from L. methylaminiphilus JLW $10^{\mathrm{T}}$ by some enzyme activities (such as oxidase, catalase, arginine dihydrolase, $\beta$-galactosidase and aesculin hydrolysis) and assimilation of some carbon substrates. In addition to physiological and biochemical evidence, fatty acid compositions, whole-cell protein profiles and
DNA-DNA hybridization tests could also be used to distinguish strain Liujia- $146^{\mathrm{T}}$ from the nearest species, $L$. monachus and L. methylaminiphilus. Therefore, based on phenotypic and phylogenetic criteria, we are of the opinion that strain Liujia-146 ${ }^{\mathrm{T}}$ merits assignment to a novel species within the genus Labrys, for which the name Labrys neptuniae sp. nov. is proposed.

\section{Description of Labrys neptuniae sp. nov.}

Labrys neptuniae (nep.tu'ni.ae. N.L. gen. n. neptuniae of Neptunia, named because the type strain was isolated from Neptunia oleracea).

Cells are Gram-negative, non-motile, non-spore-forming, capsulated, rod-shaped and multiply by budding. They are $0.7-0.9 \mu \mathrm{m}$ in diameter and $1.2-1.5 \mu \mathrm{m}$ in length. Growth is evident at temperatures between 15 and $35^{\circ} \mathrm{C}$ and at $\mathrm{pH} 4.0-10.0$; optimum growth is displayed at $28-30^{\circ} \mathrm{C}$ and $\mathrm{pH}$ 7.0-8.0. The following characters (API 20NE) are positive for the type strain: nitrate reduction, urease, aesculin hydrolysis, $\beta$-galactosidase and assimilation of glucose, arabinose, mannose, mannitol, $N$-acetylglucosamine, gluconate and malate. Negative results are displayed for oxidase, indole production, glucose fermentation, arginine dihydrolase, gelatin hydrolysis and assimilation 
Table 1. Comparison of phenotypic and biochemical characteristics between strain Liujia-146 ${ }^{\top}$, L. monachus and $L$ methylaminiphilus

Strains: 1, L. monachus VKM B-1479 ${ }^{\mathrm{T}}$; 2, L. methylaminiphilus JLW10 ${ }^{\mathrm{T}}$; 3, strain Liujia- $146^{\mathrm{T}}$ (L. neptuniae sp. nov.). +, Positive response; - , negative response; $\mathrm{W}$, weak reaction. Results were acquired in the present study, with the exception of the DNA $\mathrm{G}+\mathrm{C}$ content and major fatty acid composition data for L. monachus VKM B-1479 ${ }^{\mathrm{T}}$ and L. methylaminiphilus $\mathrm{JLW} 10^{\mathrm{T}}$, which were obtained from Miller et al. (2005). The following characters were positive for all strains: reduction of nitrate to nitrite and assimilation of arabinose, arabitol, i-erythritol, D-fructose, L-fucose, Dgalactose, $\alpha$-D-glucose, D-mannitol, D-mannose, D-psicose, methyl pyruvate, monomethyl succinate, $\beta$-hydroxybutyric acid, succinamic acid, DL-lactic acid, alaninamide, D-alanine, L-alanine, L-alanyl glycine and L-proline. All strains were negative for assimilation of D-lactose, maltose, sucrose, turanose, citric acid, D-glucuronic acid, itaconic acid, $\alpha$-ketoglutaric acid, $\alpha$-ketovaleric acid, $\alpha$-saccharic acid and $\alpha$-sebacic acid.

\begin{tabular}{|c|c|c|c|}
\hline Characteristic & 1 & 2 & 3 \\
\hline Vitamin requirement for growth & + & - & - \\
\hline Reduction of nitrate to nitrogen & - & + & + \\
\hline Oxidase & - & + & - \\
\hline Catalase & $\mathrm{W}$ & + & $\mathrm{W}$ \\
\hline Arginine dihydrolase & - & + & - \\
\hline$\beta$-Galactosidase & - & - & + \\
\hline Aesculin hydrolysis & - & - & + \\
\hline \multicolumn{4}{|l|}{ Assimilation of: } \\
\hline Tween 80 & - & - & + \\
\hline D-Raffinose & - & - & + \\
\hline D-Trehalose & - & - & + \\
\hline Gentiobiose & - & + & + \\
\hline myo-Inositol & - & + & + \\
\hline Melibiose & - & + & + \\
\hline p-Hydroxyphenylacetic acid & - & - & + \\
\hline L-Phenylalanine & - & + & - \\
\hline Putrescine & - & - & + \\
\hline 2-Aminoethanol & - & - & + \\
\hline Glycyl L-aspartic acid & - & + & - \\
\hline \multicolumn{4}{|l|}{ Major fatty acids (\%): } \\
\hline $16: 0$ & 19.7 & 17.7 & 12.9 \\
\hline $18: 1 \omega 7 c$ & 2.9 & 32.8 & 68.8 \\
\hline 19:0 cyclo & 40.4 & 49.4 & 7.8 \\
\hline $20: 1 \omega 9$ & 11.9 & - & - \\
\hline DNA G $+\mathrm{C}$ content $(\mathrm{mol} \%)$ & 68 & 65.7 & 62.7 \\
\hline
\end{tabular}

of maltose, caprate, adipate, citrate and phenylacetate. Positive results (API ZYM) are seen for activities of alkaline phosphatase, C4 esterase, leucine arylamidase, acid phosphatase and naphthol-AS-BI-phosphohydrolase and negative results are obtained for C8 lipase, C14 lipase, valine arylamidase, cystine arylamidase, trypsin, $\alpha$-chymotrypsin, $\alpha$-galactosidase, $\alpha$-glucosidase, $\beta$-glucuronidase, $\beta$-glucosidase, $N$-acetyl- $\beta$-glucosaminidase, $\alpha$-mannosidase and $\alpha$ fucosidase. The following carbon sources are oxidized (positive result with the Biolog GN2 system): glycogen, Tween 40 , Tween $80, \mathrm{~N}$-acetyl-D-galactosamine, $\mathrm{N}$-acetyl-D-glucosamine, adonitol, L-arabinose, D-arabitol, cellobiose, $i$-erythritol, D-fructose, L-fucose, D-galactose, gentiobiose, myo-inositol, lactulose, D-mannitol, D-mannose, D-melibiose, methyl $\beta$-D-glucoside, D-psicose, Draffinose, L-rhamnose, D-sorbitol, D-trehalose, xylitol, methyl pyruvate, monomethyl succinate, acetic acid, cisaconitic acid, formic acid, D-galactonic acid lactone, Dgalacturonic acid, $\alpha$-hydroxybutyric acid, $\beta$-hydroxybutyric acid, $p$-hydroxyphenylacetic acid, $\alpha$-ketobutyric acid, DLlactate, malonic acid, propionic acid, succinic acid, bromosuccinic acid, succinamic acid, glucuronamide, alaninamide, D-alanine, L-alanine, L-alanyl glycine, Lasparagine, L-aspartic acid, L-glutamic acid, glycyl Lglutamic acid, L-histidine, hydroxy-L-proline, L-leucine, L-ornithine, L-proline, L-pyroglutamic acid, L-serine, Lthreonine, DL-carnitine, $\gamma$-aminobutyric acid, urocanic acid, inosine, uridine, thymidine, putrescine, 2-aminoethanol, glycerol, DL- $\alpha$-glycerol phosphate, glucose 1-phosphate and glucose 6 -phosphate. The type strain can not oxidize $\alpha$ cyclodextrin, dextrin, $\alpha$-D-lactose, maltose, sucrose, turanose, citrate, D-glucosaminic acid, D-glucuronic acid, $\gamma$-hydroxybutyric acid, itaconic acid, $\alpha$-ketoglutaric acid, $\alpha$-ketovaleric acid, quinic acid, D-saccharic acid, sebacic acid, glycyl L-aspartic acid, L-phenylalanine, D-serine, phenylethylamine or 2,3-butanediol. The type strain is resistant to ampicillin, chloramphenicol, nalidixic acid, penicillin $G$ and rifampicin and sensitive to gentamicin, kanamycin, novobiocin, streptomycin and tetracycline. The

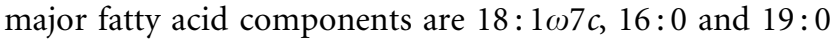
cyclo. The DNA G+C content of the type strain is 62.7 $( \pm 1.7) \mathrm{mol} \%$.

The type strain, Liujia- $146^{\mathrm{T}}\left(=\mathrm{BCRC} 17578^{\mathrm{T}}=\mathrm{LMG}\right.$ $23578^{\mathrm{T}}$ ), was isolated from root nodules of Neptunia oleracea, an aquatic legume, growing in a freshwater pond located in Tainan County in southern Taiwan.

\section{Acknowledgements}

W.-M. C. was supported by grants from the National Science Council, Taipei, Taiwan, Republic of China (NSC 94-2320-B-022-001 and 942313-B-022-001) and GN.E., E. K. J. and J. I. S. were supported by the Natural Environment Research Council (NERC), UK. We thank M. Kierans for help with the scanning electron microscopy.

\section{References}

Chen, W. M., Laevens, S., Lee, T. M., Coenye, T., De Vos, P., Mergeay, M. \& Vandamme, P. (2001). Ralstonia taiwanensis sp. nov., isolated from root nodules of Mimosa species and sputum of a cystic fibrosis patient. Int J Syst Evol Microbiol 51, 1729-1735.

Chen, W. M., James, E. K., Prescott, A. R., Kierans, M. \& Sprent, J. I. (2003). Nodulation of Mimosa spp. by the $\beta$-proteobacterium Ralstonia taiwanensis. Mol Plant Microbe Interact 16, 1051-1061.

Chung, Y. C., Kobayashi, T., Kanai, H., Akiba, T. \& Kudo, T. (1995). Purification and properties of extracellular amylase from the 
hyperthermophilic archaeon Thermococcus profundus DT5432. Appl Environ Microbiol 61, 1502-1506.

de Lajudie, P., Laurent-Fulele, E., Willems, A., Torck, U., Coopman, R., Collins, M. D., Kersters, K., Dreyfus, B. \& Gillis, M. (1998). Allorhizobium undicola gen. nov., sp. nov., nitrogen-fixing bacteria that efficiently nodulate Neptunia natans in Senegal. Int J Syst Bacteriol 48, 1277-1290.

Ezaki, T., Hashimoto, Y. \& Yabuuchi, E. (1989). Fluorometric DNADNA hybridization in microdilution wells as an alternative to membrane filter hybridization in which radioisotopes are used to determine genetic relatedness among bacterial strains. Int J Syst Bacteriol 39, 224-229.

Fritz, I., Strömpl, C. \& Abraham, W.-R. (2004). Phylogenetic relationships of the genera Stella, Labrys and Angulomicrobium within the 'Alphaproteobacteria' and description of Angulomicrobium amanitiforme sp. nov. Int J Syst Evol Microbiol 54, 651-657.

Hall, T. A. (1999). BIOEDIT: a user-friendly biological sequence alignment editor and analysis program for Windows 95/98/NT. Nucleic Acids Symp Ser 41, 95-98.

James, E. K., Sprent, J. I., Sutherland, J. M., Mclnroy, S. G. \& Minchin, F. R. (1992a). The structure of nitrogen fixing root nodules on the aquatic mimosoid legume Neptunia plena. Ann Bot 69, 173-180.

James, E. K., Minchin, F. R. \& Sprent, J. I. (1992b). The physiology and nitrogen-fixing capability of aquatically and terrestrially grown Neptunia plena: the importance of nodule oxygen supply. Ann Bot 69, 181-187.

James, E. K., Loureiro, M. de F., Pott, A., Pott, V. J., Martins, C. M., Franco, A. A. \& Sprent, J. I. (2001). Flooding-tolerant legume symbioses from the Brazilian Pantanal. New Phytol 150, 723-738.

Lee, K. B., Liu, C. T., Anzai, Y., Kim, H., Aono, T. \& Oyaizu, H. (2005). The hierarchical system of the 'Alphaproteobacteria': description of Hyphomonadaceae fam. nov., Xanthobacteraceae fam. nov. and Erythrobacteraceae fam. nov. Int J Syst Evol Microbiol 55, 1907-1919.
Mesbah, M., Premachandran, U. \& Whitman, W. B. (1989). Precise measurement of the $\mathrm{G}+\mathrm{C}$ content of deoxyribonucleic acid by highperformance liquid chromatography. Int J Syst Bacteriol 39, 159-167.

Miller, J. A., Kalyuzhnaya, M. G., Noyes, E., Lara, J. C., Lidstrom, M. E. \& Chistoserdova, L. (2005). Labrys methylaminiphilus sp. nov., a novel facultatively methylotrophic bacterium from a freshwater lake sediment. Int J Syst Evol Microbiol 55, 1247-1253.

Pot, B., Vandamme, P. \& Kersters, K. (1994). Analysis of electrophoretic whole-organism protein fingerprints. In Chemical Methods in Prokaryotic Systematics, pp. 493-521. Edited by M. Goodfellow \& A. G. O’Donnell. Chichester: Wiley.

Rivas, R., Velázquez, E., Willems, A., Vizcaíno, N., Subba-Rao, N. S., Mateos, P. F., Gillis, M., Dazzo, F. B. \& Martínez-Molina, E. (2002). A new species of Devosia that forms a unique nitrogen-fixing rootnodule symbiosis with the aquatic legume Neptunia natans (L. f.) Druce. Appl Environ Microbiol 68, 5217-5222.

Rivas, R., Willems, A., Subba-Rao, N. S., Mateos, P. F., Dazzo, F. B., Kroppenstedt, R. M., Martínez-Molina, E., Gillis, M. \& Velázquez, E. (2003). Description of Devosia neptuniae sp. nov. that nodulates and fixes nitrogen in symbiosis with Neptunia natans, an aquatic legume from India. Syst Appl Microbiol 26, 47-53.

Subba-Rao, N. S., Mateos, P. F., Baker, D., Pankratz, H. S., Palma, J., Dazzo, F. B. \& Sprent, J. I. (1995). The unique root-nodule symbiosis between Rhizobium and the aquatic legume, Neptunia natans (L. f.) Druce. Planta 196, 311-320.

Vasilyeva, L. V. \& Semenov, A. M. (1984). New budding prosthecate bacterium Labrys monahos with radial cell symmetry. Microbiology (English translation of Mikrobiologiia) 53, 68-75.

Vincent, J. M. (1970). A Manual for the Practical Study of Root Nodule Bacteria. Oxford: Blackwell Scientific.

Zurdo-Piñeiro, J. L., Velázquez, E., Lorite, M. J., Brelles-Mariño, G., Schröder, E. C., Bedmar, E. J., Mateos, P. F. \& Martinez-Molina, E. (2004). Identification of fast-growing rhizobia nodulating tropical legumes from Puerto Rico as Rhizobium gallicum and Rhizobium tropici. Syst Appl Microbiol 27, 469-477. 